\title{
Correction to: Sarecycline: First Global Approval
}

\author{
Emma D. Deeks ${ }^{1}$
}

Published online: 29 April 2019

(c) Springer Nature 2019

\section{Correction to: Drugs (2019) 79:325-329}

https://doi.org/10.1007/s40265-019-1053-4

The article Sarecycline: First Global Approval, written by Emma D. Deeks, was originally published Online First without open access. After publication in volume 79, issue 3, pages 325-329 Almirall, LLC., requested that the article be Open Choice to make the article an open access publication. Post-publication open access was funded by Almirall, LLC. The article is forthwith distributed under the terms of the Creative Commons Attribution-NonCommercial 4.0 International License (http://creativecommons.org/licenses/ by-nc/4.0/), which permits use, duplication, adaptation, distribution and reproduction in any medium or format, as long as you give appropriate credit to the original author(s) and the source, provide a link to the Creative Commons license and indicate if changes were made. Additional information for this AdisInsight Report has also been added and can be found at https://doi.org/10.6084/m9.figshare.8029316.

The original article has been corrected.

Open Access This article is distributed under the terms of the Creative Commons Attribution-NonCommercial 4.0 International License (http://creativecommons.org/licenses/by-nc/4.0/), which permits unrestricted use, distribution, and reproduction in any medium, provided you give appropriate credit to the original author(s) and the source, provide a link to the Creative Commons license, and indicate if changes were made.
The original article can be found online at https://doi.org/10.1007/ s40265-019-1053-4.

Emma D. Deeks

dru@adis.com

1 Springer, Private Bag 65901, Mairangi Bay, Auckland 0754, New Zealand 